Jurnal Interpretasi Hukum |ISSN: 2746-5047

Vol. 2, No. 2 - Agustus 2021, Hal. 315-319| Tersedia online di

https://www.ejournal.warmadewa.ac.id/index.php/juinhum

DOI: https://doi.org/10.22225/juinhum.2.2.3433.315-319

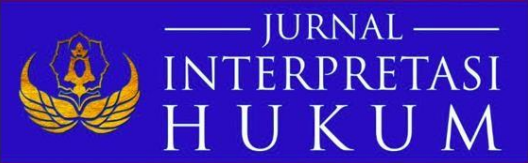

\title{
MEKANISME PENCARIAN KLAIM BADAN PENYELENGGARA JAMINAN SOSIAL (BPJS) KETENAGAKERJAAN JAMINAN HARI TUA DI TENGAH PANDEMI COVID-19
}

\author{
Kadek Yuda Kumala T.D, Anak Agung Sagung Laksrni Dewi, Ni Made Puspasutari Ujianti \\ Fakultas Hukum Universitas Warmadewa, Denpasar, Bali \\ yudakumala57@gmail.com, laksmiidewi29@gmail.com, puspasutariujianti@gmail.com
}

\begin{abstract}
Abstrak
Untuk kemanusiaan memang harus dijaminnya hak warga Indonesia atas pekerjaan serta penghidupannya. Masalah ketenagakerjaan ada kaitannya pada ciptaan iklim usaha, keamanan, kestabilan, kebijakan, serta aturan perundangan, di tingkat lokal maupun nasional. Hal itu bisa jadi faktor pendorongnya ataupun hambatannya di pekerjaan. Tujuan dari penelitian ini untuk mengetahui pengaturan hukum pengajuan klaim BPJS Ketenagakerjaan Jaminan Hari Tua di Rumah Sakit Prima Medika Denpasar dan mengethui hambatan yang dihadapi terkait proses klaim BPJS Ketenagakerjaan Jaminan Hari tua di Rumah Sakit Prima Medika Denpasar. Tipe penelitian empiris, metode pendekatan kasus, lau teknik pengumpulan datanya ialah wawancara serta studi dokumen. Hasil penelitian adalah dasarnya aturan Pemerintah No 46 Tahun 2015 tentang Penyelenggaraan Jami nan Hari Tua. Programnya ialah manfaat uang tunai yang diberi saat sudah masuk usia tertentu, tidak mau bekerja lagi, cacat total sehingga tidak bisa bekerja lagi ataupun meninggal dunia serta akan diberi sampai batas wakrunya setelah kepesertaan minimal sepuluh tahun. Kurangnya SDA untuk memberi pelayanan pada peserta klaim, sehingga pelayanan yang dilakukan juga belum efektif, dan kurangnya sosialisasi BPJS Ketenagakerjaan tentang segala hal yang berhubungan dengan pelaksanaan Jaminan Hari Tua

Kata Kunci: BPJS Ketenagakerjaan Jaminan Hari Tua, Klaim, Pekerja
\end{abstract}

\begin{abstract}
For humanity, the right of Indonesian citizens to work and livelihood must be guaranteed. Employment issues are related to the creation of a business climate, security, stability, policies, and laws and regulations, at the local and national levels. It can be a motivating factor or an obstacle at work. The purpose of this study is to find out the legal arrangements for filing claims for BPJS Employment Old Age Security at Prima Medika Hospital Denpasar and to find out the obstacles faced in the claim process for BPJS Employment Old Age Security at Prima Medika Hospital Denpasar. The type of empirical research is the case approach method, and the data collection techniques are interviews and document studies. The results of the study are basically Government regulations No. 46 of 2015 concerning the Implementation of Old Age Guarantees. The program is a cash benefit that is given when you have entered a certain age, do not want to work again, are completely disabled so they cannot work again or die and will be given until the time limit after a minimum of ten years of participation. Lack of natural resources to provide services to claim participants, so that the services provided are also not effective, and the lack of socialization of BPJS Employment on all matters relating to the implementation of Old Age Security.
\end{abstract}

Keywords: BPJS Employment, Old Age Security, Claims, Workers.

\section{PENDAHULUAN}

Semua warga Indonesia memang harus dijamin haknya dan penghidupannya agar layak. Tapi sampai sekarang persoalan yang dasar terjadi ialah kerja dan penghidupan yang belum layak. bukan hanya pemerintah tetapi juga bagi dunia usaha serta masyarakat. dibangunnya ekonomi yang basis modalnya tidak bisa diselesaikannya semua masalah ketenagakerjaan misal kesempatan kerja, nganggur, serta miskin. Masai ah perekonomiannya tidak hanya bersangkut masalah pekerjaan serta penghidupan yang layak tapi terdapat struktur lapangan kerja serta status pekerjaan, tingkatan upah serta penghasilan yang relative kecil pada kebutuhan hidup layak, masalah kompetensi serta produktivitasnya yang kurang bisa bersaing, serta masalah ketenagakerjaan lain yang saling mengait (Abdul Khakim, 2003).

Masalah ketenagakerjaan punya kaitan yang luas pada ciptaan iklim usaha, keamanannya, kestabilannya, kebijakannya, serta peraturan perundangannya, baik di tingkat lokal maupun nasional. 
Hal itu bisa jadi sebab dorongan ataupun hambatan proses produksinya barang serta jasa misal supply serta distribusi, serta minat investor untuk menanarn modalnya di Indonesia. Adanya Jaminan sosial untuk tenaga kerja yg dibuat oleh badan hukum publik ini khusus untuk menangani resiko yang dialami di dunia kerja serta ditingkatkannya kesejahteraan pekerja, program ini dibuat untuk memberi perlindungan untuk pekerja serda dijaganya dan diatasinya masalah sosial ekonominya muncul dan menaikan sejahteranya rakyat.

Perlindungan yang diberi BPJS ketenagakerjaan batasanya memberi pencegahan pada risiko sosial yang terjadi misla celaka kerja, sakit, pensiun, serta resiko lain yang berakibat kurangnya jumlah tenaga kerja saat cari penghasilannya. bagi penyelenggara jaminan sosial yaitu ada program, BPJS Ketenagakerjaan tugasnya serta kewajibannya adalah pungut iuran lewat peserta serta pemberi kerja untuk lanjutnya dikelola serta dikembangkannya diberi manfaat pada seluruh peserta (Lalu Husni, 2003).

Program yang diselenggarakannya oleh BPJS Ketenagakerjaan sekarang dirasa punya manfaat besar oleh peserta BPJS Ketenagakerjaan ialah jaminan hari tua. Dasar aruran pemerinta No 46 Tahun 2015 mengenai Penyelenggaraan hari rua. Program itu ialah dimanfaatkannya uang tunai yang diberi ketika masuk usia tertentu, tidak mau kerja lagi, cacat total lalu tidak bisa kerja lagi ataupun meninggal dunia serta akan diberi sampai batas waktunya itu sesudah kepesertaannya minimal sepuluh tahun (Sholiha Afif Fauziyani dan Warsono, Hadi, 2018: 112)

Jaminan Hari Tua adalah sebuah program nilai yang milikinya punya manfaat sangat besar yaitu menopang hidup tenaga kerja, saat ini ataupun masa tua nanti. Jaminan hari tua bisa jadi untuk tabungan masa depan saat dihadapinya risiko seperti saat ini covid -19 serta sosial ekonomi. pada kondisi saat ini dana Jaminan Hari Tua yang sebagiannya dihimpun dari tenaga kerja sangat perlu juga untuk ditopangnya kehidupan walaupun masih dalam usia produktif. Manfaat Jaminan Hari Tuanya bisa diterima saat peserta stop bekerja, serta tidak lagi harus nunggu kepesertaan minimal 10 tahun.

Sejak diaktifkan pada pertengahan Maret, protokol layanan tanpa kontak fisik (Japak fisik) telah mendapatkan respon positif dari pekerja. Dalam pengurusan kJaim Jaminan Hari Tua, di himbau pekerja untuk menghindari praktek percaloan dikarenakan banyaknya peserta yang enggan mempelajari prosedur pengajuan. Masa pandemi covid 19, pembayaran klaim meningkat pada bu Ian Agustus dan September. Peningkatan klaim Jaminan Hari Tua BPJS Ketenagakerjaan karena banyaknya masyarakat yang kehilangan lapangan pekerjaan akibat perusahaan yang berhenti beroperasional. sehingga program Jaminan Hari Tua menjadi pemasukan atau tabungan bagi mereka guna menjamin kelangsungan hidup. Jaminan Sosial Tenaga Kerja adalah upaya bijaksananya yang ditunjuk untuk tenaga kerja, utamanya yang ada di lingkungan perusahaannya di penyelenggaraannya, perlindungan dengan interaksi kerja yang saling bikin untung kedua pihak (Tenaga kerja serta pengusaha). Program ini dasarnya bisa dipengaruhi oleh kondisi penduduk yang mempengaruhi pembangunan kependudukannya. Semua orang yang kerja butuh jaminan sosial untuk menjamin kehidupannya, tapi tidak semua pekerja punya jaminan sosial yang bisa menjamin kehidupannya (Sentanoe Kertonegoro, 1984).

Namun proses pencairan tersebut tidak begiru mudah,karena, adanya tahapan-tahapan yang harus ditaati sesuai prosedur yang berlaku. Dalam proses yang dilalui ditemukan berbagai hambatan dalam pencairan klaim jaminan hari tua BPJS Ketenagakerjaan. Demikianlah perlunya ketenangan serta sehatnya pekerja supaya apa yang dihadapinya di pekerjaan dapat diperhatikan semaksimal mungkin, sehingga waspada pada menjalankan pekerjaan itu tetap ada jaminannya. Pemikiran itu ialah program perlindungan pekerja, yang dalam praktik sehari-hari berguna buat bisa melihat aktivitas serta stabilnya perusahaan.

Badan Penyelenggara Jaminan Sosial merupakan sebuah badan hukum untuk menyelenggarakan program jaminan sosial untuk menjamin seluruh rakyat agar dapat memenuhi kebutuhan dasar hidup yang layak. BPJS diselenggarakan berdasarkan asas kemanusiaan, manfaat, dan keadilan sosial bagi seluruh rakyat Indonesia dengan tujuan untuk mewujudkan pemenuhan kebutuhan dasar hidup yang layak bagi setiap rakyat Indonesia yang sudah menjadi hak dasar manusia (Solechan, 2019). Menurut Zahri Vandawati(2020) Pemerinah membentuk BPJS Kesehatan sebagai upaya untuk meningkatkan kesejahteraan masyarakat, yang menangani jaminan sosial di bidang kesehatan seluruh masyarakat Indonesia. BPJS Kesehatan merupakan program JKN dengan system pelayan asuransi. Menjadi peserta BPJS Kesehatan merupakan program wajib dari pemerintah yang 
dapat melindungi dan memberikan pelayanan kesehatan kepada warganya. Sedangkan menurut Akhmad Purnama (2015) Pembangunan kesejahteraan sosial bertujuan untuk mewujudkan kehidupan yang layak dan bermartabat, serta untuk memenuhi hak atas kebutuhan dasar warga Negara. Pembangunan kesejahteraan sosial adalah usaha yang terencana dan melembaga yang meliputi berbagai bentuk terarah, dan berkelanjutan. Salah satu upaya mewujudkan taraf kesejahteraan sosial adalah melalui jaminan sosial. Jaminan sosial sebagai skema yang melembaga untuk menjamin seluruh rakyat agar dapat memenuhi kebutuhan dasar hidupnya yang layak (Undang-undang No 11 Tahun 2009).

Dari paparan penjelasan diatas dapat dirumuskan tujuan dari penelitian ini untuk mengetahui pengajuan kl aim bpj s ketenagakerjaan jaminan hari tua di ru mah sakit prima medika Denpasar. mengetahui hambatan yang dihadapi terkait proses klaim bpjs ketenagakerjaan jaminan hari tua di rumah sakit prima medika denpasar.

\section{METODE PENELITIAN}

Tipe penelitian hukurnnya digunakan di penelitian ini adalah jenis penelitian empiris ialah satu cara yang bisa dipakai untuk didapat kebenaran, yaitu dengan membandingkan peraturan-peraturan yang ada dengan pelaksana secara nyata dalam masyarakat (Send jun Manulang. 1990). Sumber Data yang digunakan adalah Data Primer diperoleh dari, Kepala Bagian Casemix, di Rumah Sakit Prima Medika Denpasar, Kepala Bidang SDM, Kepala Bidang Keuangan dan Kepala Pajak Rumah Sakit Prima Medika Denpasar, bagaimana pencairan klaim BPJS Ketenagakerjaan Jaminan Hari Tua bisa dilakukan dalam ketentuan dan syarat-syarat sesuai peraturan. Surnber datanya seperti sekunder ialah semua publikasi terkait hukum yang tidak berupa dokumen resmi. penyebaran tentang hukum terdiri dari teks buku, kamus hukum, jumal hukum, serta putusan hukum (Soerjono Soekanto, 2014 21). Teknik Pengumpulan Data dilakukan dengan Teknik wawancara Wawancara ini dilaksanakannya dengan diajukannya daftar soal secara sistematis. Teknik Studi Dokumen adalah Teknik pertama yang dipakai di tiap penelitian ilmu hukum, baik normatif maupun empiris Teknik Observasi/Pengamatan. Teknik Observasi bedanya ada dua ialah Teknik observasi langsung serta tidak langsung.

\section{HASIL PENELITIAN DAN PEMBAHASAN}

\section{Pengajuan Klaim BPJS Ketenagakerjaan Jaminan Bari Tua Di Rumah Sakit Prima Medika Denpasar}

Setiap karyawannya harus didaftarkan oleh perusahaan ke BPJS kesehatan serta ketenagakerjaan,jika anda adalah karyawan perusahaannya maka anda seharusnya didaftarkan oleh perusahaan untuk jadi peserta BPJS kesehatan yang ditanggung nya oleh perusahaan serta jug a BPJS ketenagakerjaan yang setengah iuran bulannya ditanggung oleh perusahaannya.

BPJS Ketenagakerjaan adalah program pemerintah yang memberi penjamin sosial ekonomi pada para pekerja yang kerja di indonesia, program ini sebetulnya bukan program baru, tapi ini program alihan dari program yang lama yaitu Jaminan Sosial Tenaga Kerja ataupun lebih kita kenal JAMSOSTEK. Karena ini adalah program alihan dari jamsostek, programnya pun tidak jauh bedanya dari program yang jamsostek punya sebelumnya, tapi pun ya sedikit perubahan (Agusmidah, 2010 90).

Jaminan Hari Tua adalah sebuah program yang punya nilai serta memiliki manfaat besar untuk menyangga hidupnya tenaga kerja, baik saat ini ataupun tua nanti. Jami nan hari tua bisa jadi sebagai tabungan rnasa depan buat berhadapan jika terjadi resiko seperti saat ini covid -19 serta sosial ekonomi. Di kondisi saat ini dana Jaminan Hari Tua yang setengahnya dihimpun dari tenaga kerja sangat perlu juga buat menopang hidup walau masih di usia produktif. Manfaatnya Jaminan Hari Tua bisa diterima saat peserta berhenti bekerja, serta tidak lagi harus nunggu pastinya minimal 10 (sepuluh tahun) Program JHT BPJS Ketenagakerjaan dibuat supaya peserta bisa dapat manfaat meskipun sudah pensiun ataupun tidak kerja lagi di suatu perusahaan. Tapi, tidak semua orang tahu cara cairkan BPJS Ketenagakerjaan program JHT saat pandemi Covid-19. Kasus COVID-19 yang masih terus dijumpai per hari membuat sedikitnya kantor memilih melayani masyarakat lewat online, supaya menekan risiko kontak fisik saat dicairkannya dana. Cara cairkan JHT BPJS lewat online atau offline harus diikutinya syarat serta ketenruan yang berlaku. Tapi dicairkannya lewat online membuat anggota tidak perlu ke kantor ataupun berada di sekitar antrian yang resikonya tinggi terpapar virus corona. 


\section{Hambatan yang Dihadapi Terkait Proses Klaim BPJS Ketenagakerjaan Jaminan Hari Tua Di Rumah Sakit Prima Medika Denpasar}

Saat penyusunan skripsi ini, penelitian dilakukan lewat pengambilan lokasi di Rumah Sakit Prima Medika Kota Denpasar terkait pegawai yang mengikuti dan mengklaim BPJS Ketenagakerjaan Jaminan Hari Tua. Dalam penelitian, alasan penulis memilih objek penelitian tersebut dengan alasan bahwa:

1. Rumah Sakit Prima Medika adalah salah satu rumah sakit yang sudah beroperasi sejak lama dan mewajibkan pekerjanya untuk memil iki BPJS Ketenagakerjaan, yang salah satu programnya menyangkut jaminan Jaminan Hari Tua.

2. Klaim BPJS Ketenagakerjaan di Rumah Sakit Prima Medika sudah tercatat dan diurus langsung oleh pihak yang profesional yang bergelut di bidang tersebut. Sehingga kelengkapan data didapatkan secara faktual.

Hambatan External Dalam proses pencairan klaim BPJS Ketenagakerjaan Jaminan Hari Tua harus dilakukan secara mandiri. Sesuai dengan ketentuan, bahwa pekerja di Rumah Sakit Prima Medika yang terdaftar memiliki BPJS Ketenagakerjaan Jaminan Hari Tua berhenti bekerja atau resign. Sehingga pihak Rumah Sakit Prima Medika tidak memiliki wewenang membantu proses pencairan klaim. Proses klaim BPJS Ketenagakerjaan Jaminan Hari Tua mengalami beberapa kendala, ialah:

a. Jarak waktu proses cairnya santunan Jaminan Hari Tua yang lama.

b. Kurang sosialisasi BPJS Ketenagakerjaan mengenai semua hal yang ada hubungan di pelaksanaan JHT

c. kurang sarana serta prasarana layanan yang diberi BPJS Ketenagakerjaan mengakibatkan tumpukan antrian yang cukup lama.

d. Pemahaman digitalisasi yang kurang.

e. Sinkronisasi Data diri yang dimiliki oleh pemilik BPJS Ketenagakerjaan harus sama dengan kartu BPJS yang dimiliki.

Hambatan Internal Kendala yang ditemui oleh pihak pekerja dalam proses pencairan klaim BPJS Ketenagakerjaan Jaminan Hari Tua sangat beragam. Salah satunya memerlukan bantuan dari pihak Instansi atau tempat bekerja terdahulu, dalam penelitian ini adalah Rumah Sakit Prima Medika, Adapun hambatan kelengkapan data dari pihak Rumah Sakit Prima Medika, adalah sebagai berikut:

a. Surat Pengalaman Kerja, Paklaring (surat pengalaman kerja) merupakan salah satu syarat mutlak yang perlu dilengkapi

b. Nomor Kartu BPJS TK (Tenaga Kerja), Syarat lain yang harus dipenuhi dalam klaim BPJS Ketenagakerjaan Jaminan Hari Tua adalah memberikan karru BPJS TK.

\section{SIMPULAN DAN SARAN}

\section{Simpulan}

Dari uraian penjelasan diatas, maka si mpulan dari penelitian ini yaitu atas dasar Peraturan Pemerintah No 46 Tahun 2015 mengenai Penyelenggaraan Jaminan Hari Tua. Program itu ialah memanfaatkan uang tunai yang diberi saat masuk usia tertentu, tidak mau bekerja lagi, cacat total berakibat tidak mampu kerja lagi ataupun meninggal dunia serta akan diberikannya sampai batas waktu tertentu sesudah kepesertaannya minimal sepuJuh tahun. program ini dinilai punya manfaat begitu besar pada penyangga kehidupan tenaga kerja, saat ini ataupun dimasa tua nanti. Jaminan hari tua bisa jadi sebagai tabungan masa depan untuk dihadapinya risiko-risiko seperti saat ini covid -19 serta sosial ekonomi. Di suasana tertentu saat ini dana Jaminan Hari Tua yang sebagian dihimpun dari tenaga kerja sangat perlu juga untuk menyangga kehidupan walaupun masih dalam usia produktif. Manfaat Jaminan Hari Tua dapat diterima ketika peserta berhenti bekerja, dan tidak lagi hams menunggu kepesertaan minimal IO (sepuluh tahun). Kurangnya SDA untuk memberikan pelayanan secara maksimal kepada peserta klaim, sehingga pelayanan yang dilakukan juga belum efektif, dan kurangnya sosialisasi BPJS Ketenagakerjaan tentang semua hal yang ada hubungan di pelaksanaannya JHT, lalu menyebabkan keengganan dan salah paham mengenai haknya sebagai peserta BPJS Ketenagakerjaan. 


\section{Saran}

Beberapa saran yang diperoleh dari hasil penjelasan dan simpulan peneliti yakni:

1. Sumber Daya Manusia yang dimiliki, supaya lebih ditingkatkan lagi, bagi masyarakat atau pekerja terlayani dengan baik, khususnya dalam pelayanan klaim BPJS Ketenagakerjaan Jaminan Hari Tua di Rumah Sak.it Prima Medika.

2. Bagi Pemerintah, Sosialisasi yang diupayakan agar terus dilaksanakan secara menyeluruh kepada seluruh masyarakat atau yang bekerja baik di sektor formal maupun informal khususnya di bagian Sumber Daya Manusia di Rumah Sakit Prima Medika agar ditingkatkan lagi, karena jika sosialisasi ini tidak dilaksanakan secara maksimal, maka target yang akan dicapai tidak terlaksana.

3. Perlu untuk ditinjau kembali peraturan pemerintah yang mengatur tentang pelaksanaan program Jaminan Hari Tua ini, karena jika hal ini tidak diperhatikan secara serius, rnaka program Jaminan Hari Tua akan kehilangan tujuannya. Harus memiliki kerja sama yang baik dengan pihak-pihak pekerja di bagian SOM yang ditempatkan sesuai di masing-masing bidang yang mengurus program BPJS Ketenagakerjaan Jarninan Hari Tua di bagian SDM Rumah Sakit Prima Medika Denpasar.

\section{DAFTAR PUSTAKA}

Agusmidah. (2010). Hukum Ketenagakerjaan Indonesia.Ghalia Indonesia. Bogor.

Akhmad Purnama. (2015). Analisis Perlindungan Jaminan Sosial bagi Pekerja Informal. PKS, Vol 14(2), 149-162.

Chumaida, Z. V. (2020). Kepesertaan Program Bpjs Kesehatan Di Tengah Wabah Pandemic Covid-19. Lex Jurnal: Kajian Hukum Dan Keadilan, Vol 4(2).

Fauziyani, S. A., \& Warsono, H. (2018). Analisis Kualitas Pelayanan Program Jaminan hari Tua Badon Penyelenggaraan Jaminan Sosial (BPJS) Ketenagakerjaan.

Husni, L. (2013). Pengantar Hukum Ketenagakerjaan Indonesia. PT. Raja Grafindo Persada. Jakarta.

Kertonegoro, S. (1984). Jaminan Sosial Prinsip dan Pelaksanaannya di Indonesia. Mutiara Sumber Widya. Jakarta.

Khakim, A. (2003). Pengantar Hukum Ketenagakerjaan Indonesia. Pt.Citra Adirya. Bandung.

Manulang, S. (1990). Pokok-Pokok Hukum Ketenagakerjaan. Rineka Cipta. Jakarta.

Manulang, S. (2014). Pengantar Penelltian Hukum. Universitas Indonesia.

Solechan. (2019). Badan Penyelenggara Jaminan Sosial (BPJS) Kesehatan Sebagai Pelayanan

Publik. Adminitrative Law \& Governance, Vol 2(4). 